Cronfa - Swansea University Open Access Repository

This is an author produced version of a paper published in :

Youth Justice

Cronfa URL for this paper:

http://cronfa.swan.ac.uk/Record/cronfa7089

\title{
Paper:
}

Hoffman, S. \& Macdonald, S. (2011). Tackling youth anti-social behaviour in devolving Wales: a study of the tiered approach in Swansea. Youth Justice, 11(2), 150-167.

http://dx.doi.org/10.1177/1473225411406382

This article is brought to you by Swansea University. Any person downloading material is agreeing to abide by the terms of the repository licence. Authors are personally responsible for adhering to publisher restrictions or conditions. When uploading content they are required to comply with their publisher agreement and the SHERPA RoMEO database to judge whether or not it is copyright safe to add this version of the paper to this repository. http://www.swansea.ac.uk/iss/researchsupport/cronfa-support/ 


\section{Tackling Youth Anti-Social Behaviour in Devolving Wales: \\ A Study of the Tiered Approach in Swansea}

\begin{tabular}{|c|c|c|}
\hline s: & $\begin{array}{l}\text { Dr Simon Hoffman } \\
\text { School of Law, } \\
\text { Swansea University, } \\
\text { Singleton Park, } \\
\text { Swansea. SA2 8PP } \\
\text { Tel: (01792) 603004 } \\
\text { Fax: (01792) 295855 } \\
\text { E-mail: s.hoffman@ swansea.ac.uk }\end{array}$ & $\begin{array}{l}\text { Dr Stuart Macdonald } \\
\text { School of Law, } \\
\text { Swansea University, } \\
\text { Singleton Park, } \\
\text { Swansea. SA2 8PP } \\
\text { Tel: (01792) 602411 } \\
\text { Fax: (01792) 295855 } \\
\text { E-mail: s.macdonald@ swansea.ac.ul }\end{array}$ \\
\hline
\end{tabular}

Dr Simon Hoffman is a Lecturer at the School of Law, Swansea University.

Dr Stuart Macdonald is a Senior Lecturer at the School of Law, Swansea University. 


\title{
Tackling Youth Anti-Social Behaviour in Devolving Wales: A Study of the Tiered Approach in Swansea
}

\begin{abstract}
Taking youth anti-social behaviour as its focus, and drawing upon a recently completed study of the operation of the tiered approach to youth anti-social behaviour in Swansea, this article examines the important effects on youth justice of both devolution and the mediation of policy by practitioners. The discussion of the policy agendas of the Westminster and Welsh Assembly Governments and the accounts of stakeholders in Swansea is structured around the following themes: de-escalation and diversion; consistency and avoiding net-widening; inclusionary welfarism and multiagency partnership; and voluntarism, engagement and compliance.
\end{abstract}

Keywords: anti-social behaviour; youth justice; devolution; tiered approaches

Word count (inc. references and table 1 but excluding abstract): 8657 


\section{Tackling Youth Anti-Social Behaviour in Devolving Wales: A Study of the Tiered Approach in Swansea}

Two months after being appointed Home Secretary Theresa May promised a 'new approach' to tackling anti-social behaviour, criticising the 'top-down', 'centralised', 'bureaucratic' and 'gimmick-laden' approach of New Labour (May 2010). The subsequent consultation paper, More Effective Responses to Anti-Social Behaviour, proposed an approach which is 'fundamentally local', which vests more discretion in frontline professionals and enhances local accountability, and which is simpler and less bureaucratic (Home Office 2011). Focussing specifically on young people, this article presents the findings of interviews with those involved in tackling youth anti-social behaviour in Swansea. ${ }^{1}$ It argues that these findings provide evidence of a distinctively Welsh approach to youth justice, emanating from the Welsh Assembly Government, and suggests that the experiences of those working in Swansea might inform the development of the new approach promised by the coalition Con-Lib Government.

New Labour introduced a vast array of tools and powers to tackle anti-social behaviour. At least 35 were listed in the guidance it published in 2008 (Home Office 2008). ${ }^{2}$ In many areas relevant authorities organized the various different interventions hierarchically, with informal measures such as warning letters and visits employed first, then some form of 'regulated self-regulation' using a non-enforceable contractual agreement (Crawford 2003), and formal court-based interventions only utilized if these fail. This 'tiered' approach was encouraged by Home Office guidance, which stated that 'Where applicable, these interventions should be used incrementally as independent reports have shown that this is what works' (Home Office 2008: 1). It also found support in the 2005 report of the Home Affairs Committee (which noted 'the strength of the evidence [it had] received in favour of a tiered approach' (Home Affairs Committee 2005: volume I, para 369)) and the study completed the following year by the National Audit Office (National Audit Office 2006). The coalition Government, however, has expressed concern about such an approach, stating that it 'risks prolonging the length of time a victim or community has to suffer [anti-social] behaviour' (Home Office 2011: 10). Instead, the coalition has set out a pyramid of interventions which includes: informal restorative justice; warning letters and Acceptable Behaviour Contracts (ABCs); rehabilitative, restorative out-of-court disposals; and new Crime Prevention Injunctions and Criminal Behaviour Orders. This is clearly stated not to be an 'escalator' 'practitioners need to choose the approach most appropriate for the behaviour in question and do not need to start at the bottom' (Home Office 2011: 13).

The 'transformation' promised by the Home Secretary (Home Office 2011: 1) is a stark example of the temporal specificity of law and policy. But, as Goldson and Hughes have explained, youth justice laws and policy are also spatially specific. They 'vary between jurisdictions and, in some cases, within jurisdictions' (Goldson and Hughes 2010: 212 (emphasis original)). This article pursues each of these themes. It argues, first, that in the years since the Government of Wales Act 1998 the Welsh Assembly Government has developed its own, distinctive approach to youth

\footnotetext{
${ }^{1}$ The report was supported by a grant from the Welsh Assembly Government Department for Social Justice under the New Ideas research programme.

${ }^{2}$ Depending on how one counts the tools and powers listed, it would be possible to arrive at an even higher number (if, for example, prosecution for drugs offences and prosecution for motoring offences were to count as two separate powers, and one were to include such things as 'housing support').
} 
justice. This differed significantly from New Labour's 'New Youth Justice' (Goldson 2000), thus calling into question whether England and Wales can still be regarded as a single jurisdiction notwithstanding the fact that youth justice is not formally a devolved matter. Second, the article recognises that governmental policies are 'mediated by the practitioners tasked with implementing them' (Kemshall 2008: 29). The rhetorical, the codificational and the implementational are different modes of policy involving different processes and different categories of actors (Fergusson 2007). So while New Labour's youth justice policy was characterized by the 'politics of toughness' (Goldson and Muncie 2006: 210) and institutionalized intolerance (Muncie 1999), local implementation was 'by no means a uniform or uncontested tale of growing authoritarianism and institutionalised intolerance' (Hughes and Follett 2006: 169). Rather, different localities were 'characterised by an uneven mix of enthusiasm, co-operation alongside wary compliance and gentle contestation with the government's moral communitarian and popular punitive agenda' (Hughes and Follett 2006: 165). In a similar vein, there are indications that the Welsh Assembly Government's distinctive approach has been implemented unevenly across Wales. The contention of this article will be that Swansea's approach to tackling youth antisocial behaviour does embody key features of the Welsh Assembly Government's youth justice policy.

The research for the Swansea study was carried out with agencies closely involved in tackling youth anti-social behaviour in the city. A qualitative methodology was adopted. Interviews were carried out both with individuals with strategic planning responsibilities and those with operational casework responsibilities. These individuals were from the Safer Swansea Partnership (SSP), the police, the Youth Offending Team (YOT) and the Anti-Social Behaviour Unit (ASB Unit). Interview schedules were drawn up on key themes following a review of policy documents from the Westminster and Welsh Assembly Governments, documents provided by the SSP and YOT and preliminary discussions with participants. The research was conducted between January and July 2009. After describing and contextualising the tiered approach which has been, and continues to be, employed in Swansea, the findings from the interviews will be presented around the following themes: de-escalation and diversion; consistency and avoiding netwidening; inclusionary welfarism and multi-agency partnership; and voluntarism, engagement and compliance.

\section{The context and operation of Swansea's tiered approach to youth anti-social behaviour}

Although youth justice formally remains a non-devolved policy domain, the core services comprising YOTs derive from wholly devolved areas of policy. So 'While there is an absence of any formal responsibility for youth justice or YOTs, at the devolved level, almost all the services on which YOTs have to rely for their direct functioning, and in order to carry out their responsibilities, lie under the control of the [Welsh] Assembly' (Drakeford 2010: 140). Youth justice in Wales has therefore proceeded on a negotiated basis. This has taken place in the context of a Welsh children's policy which differed markedly from the approach of New Labour in England. Explicitly based on the United Nations Convention on the Rights of the Child (the 'UNCRC'), Welsh children's policy 'adopts a language of justice, equality and participation', with a model of children and young people that is 'confident, positive, imaginative and optimistic' (Drakeford 2010: 144). This distinctive policy 
agenda - which holds that youth offending should be understood as only one element in a much wider and more complex identity, and that the focus should be on trying to put right flaws in the systems on which young people depend rather than deficits in the young people themselves (Drakeford 2010: 141) - underlies the principles contained in the All Wales Youth Offending Strategy (Welsh Assembly Government 2004) and is at the heart of the 'Dragonisation' of youth justice (Edwards and Hughes 2009; Haines 2009). The centrality of the UNCRC will be advanced still further by the Rights of Children and Young Persons Measure. This primary legislation, which was passed by the National Assembly for Wales in January 2011, will require all Welsh Assembly Ministers to have due regard to the Convention in the exercise of all their functions, including those relating to youth justice.

Whilst the Welsh Assembly Government has been able to negotiate this divergence from England, some points of tension and lack of clarity remain (Muncie 2011). Haines, for example, has noted how the All Wales Youth Offending Strategy talks of public protection, early intervention and appropriate punishment (YJB goals) alongside maximum diversion, minimal formal intervention and penal reductions (Welsh Assembly Government goals) (Haines 2009). Moreover, it is important to recognise that differences within jurisdictions may be greater than some differences between them (Muncie 2011). Drakeford has noted the gaps that exist across Wales between the Welsh Assembly Government's rights-based policy ambitions and the delivery of services at local level (Drakeford 2010). In addition, there are wide variations in the way in which Welsh YOTs have been constituted, funded and managed (Morgan 2009). And there are 'large, regular and longstanding' differences in custody rates. In 2008/09, Merthyr Tydfil had the highest proportionate use of custodial court sentences of all 157 YOT areas in England and Wales, at 20.2\%. This contrasts starkly with Newcastle, which is also characterised by a high incidence of deprivation and yet has a custodial sentencing rate of 2.5\% (Morgan 2009: 64).

In Swansea, a positive, pro-social, child-rights perspective has been evident the mid-1990s, pre-dating devolution. During this time agencies including the local authority, Youth Offending Service and police have collaborated to tackle issues which negatively affect children and lead to offending behaviour (Haines and Charles 2010). Examples include: work aimed at improving educational attainment (Haines and Case 2003) and reducing substance use (Haines and Charles 2008); and evolving programmes to promote participation and community engagement (Case 2004; Swansea Youth Action Network 2010). These programmes have been characterized by their multi-agency nature, demonstrating that traditional barriers between agencies have not prevented effective inter-agency co-operation and shared commitment to a common philosophy (Haines and Charles 2010). Key to achieving this, according to our interviewees, has been the vision of key personnel (I4; I5; I7) and stable leadership within relevant agencies, which has ensured consistency and allowed working relationships to develop (I1; I8; I9).

The operation of Swansea's tiered approach to youth anti-social behaviour must be understood against this background. Although the four LCJB areas in Wales, and many areas in England, have all adopted a tiered approach to youth anti-social behaviour, there has been uneven and uncertain implementation of tiered approaches across different sites (Hughes and Follett 2006). In Swansea, the day-to-day operation of the tiered approach is handled by the Anti-Social Behaviour Unit (ASB Unit). This consists of four members: the Anti-Social Behaviour Reduction Coordinator (ASB Reduction Co-ordinator; employed by the Safer Swansea Partnership); the Anti-Social Behaviour Reduction Officer (ASB Reduction Officer; a 
police officer); and the Anti-Social Behaviour Case Manager (ASB Case Manager) and Acceptable Behaviour Project Worker (both employed by the YOT). Partner agencies, such as the police and housing, acquire information on youth anti-social behaviour in the discharge of their various functions, and are responsible for deciding whether or not to make a referral to the ASB Reduction Co-ordinator. Where a referral is made the ASB Reduction Co-ordinator will carry out an evaluation of the reported incident(s). The possible responses are: no action (where the complaint is unsubstantiated, the behaviour complained of is of a minor nature, or the source of the information is unreliable); the standard tiered approach; or, in the case of more serious incidents, fast-tracking directly to stage three.

At stage one a letter is sent to the young person warning of the consequences of any further incident. In the case of those under 16 years a letter is also sent to their parent or guardian. If a second incident is reported within six months the case moves to stage two. A second warning letter will be sent to the individual concerned (and, where applicable, their parent/guardian), and arrangements will be made for the ASB Reduction Officer and ASB Case Manager to visit the young person in their home. At the visit the young person will be asked to sign a Personal Warning. The object of the visit is twofold: first, to warn the young person that their behaviour is unacceptable and that an improvement is required; and second, to seek more information about the young person and their circumstances in order to attempt to identify any factors which could be relevant to their conduct. Where underlying problems are identified, the young person may be offered specialist services. If the young person rejects offers of assistance a full record of the interview will be kept but no further action will be taken.

Where there have been further incidents of anti-social behaviour following a stage two warning letter (or where a case has been fast-tracked) a stage three case conference is called. This is attended by all relevant agencies and the individual concerned. At the case conference a range of informal interventions will be considered, including Family Group Conferencing (FGC), an $\mathrm{ABC}$ and/or a Parenting Contract. If there is a FGC this will work with the family of the young person to produce an Action Plan which will include timescales and will identify interventions aimed at stopping the anti-social behaviour. The interventions will be agreed between the family, the FGC Team and the ASB Unit. Alternatively, it may be decided that the young person should be asked to sign an $\mathrm{ABC}$. The signing of an $\mathrm{ABC}$ by a young person and, if appropriate, his parent or guardian, will be preceded by a meeting attended by those individuals and other relevant agencies.

The final stage of the tiered approach is to apply for an Anti-Social Behaviour Order (ASBO), with the added possibility of a Parenting Order and/or Individual Support Order in the case of a young person. An application for an ASBO is seen as a last resort, to be considered only where all other measures have failed or where the behaviour is so serious that there is a pressing need to place restrictions on the behaviour. In all but the most urgent cases a stage three case conference will be held prior to the ASBO application, with all relevant agencies consulted.

Data on the number of interventions at each stage of Swansea's tiered approach during the years 2004-2009 shows a high rate of attrition between each stage (see table 1). For example, in each of the six years the number of stage two letters sent to perpetrators of all ages is never greater than $22 \%$ of the number of stage one letters sent, and the numbers of ABCs agreed with young people is never greater than $12 \%$ of the number of stage 2 warning letters sent to young people. In fact, during these six years only three cases worked their way through all four stages of the 
tiered approach and culminated in an ASBO being imposed on a young perpetrator of anti-social behaviour. This accords wells with the coalition Government's stated aims of ensuring that informal interventions are effective, preventing perpetrators from progressing to more serious anti-social behaviour, and avoiding the unnecessary criminalisation of young people (Home Office 2011).

Table 1 here

\section{De-escalation and diversion}

According to self-report studies, offending and anti-social behaviour are so prevalent in the teenage years that they can be viewed as a relatively normal feature of adolescence. All but a small minority will be 'adolescent-limited offenders' (Moffitt 1993) and will grow out of crime and anti-social behaviour (Rutherford 1992). Interactionist, social reaction and labelling perspectives accordingly urge the importance of diversionary strategies which seek to prevent young offenders from entering the formal youth justice system (Goldson 2000). Findings from the Edinburgh Study of Youth Transitions and Crime also suggest that early intervention is iatrogenic. Those who are sucked into the youth justice system from an early age are not always the most serious and prolific offenders, and entering the system can result in repeated and amplified contact (McAra and McVie 2010). In short, 'social control leads to deviance' (Lemert 1967: v). Yet in spite of this, one of the cornerstones of New Labour's 'New Youth Justice' was the movement away from diversion towards early intervention (Goldson 2000). And there are indications that this movement will continue under the coalition Government. Justice Minister Crispin Blunt has stated that most existing prevention programmes focus on young people who are already on the fringes of criminality, and more investment is needed in earlier interventions (Puffett 2011). A Ministry of Justice Green Paper has accordingly suggested that Department for Education early intervention grants be used to develop programmes for children and families at risk of offending or antisocial behaviour (Ministry of Justice 2010).

The manner in which New Labour deployed regulatory ideas in its anti-social behaviour agenda was symptomatic of its early interventionism. Crawford described how, in this context, 'regulatory ideas are being deployed in ways that (either intentionally or inadvertently) can frequently serve to lower the threshold of intervention, formalize previous informal responses, intensify forms of intervention and hasten punishment' (Crawford 2009: 812). In particular, the notion of a 'regulatory pyramid' (Ayres and Braithwaite 1992; Braithwaite 2002) was interpreted by New Labour in a way which 'conforms more closely to a ladder (or escalator!), where each subsequent intervention is more serious than the first. Each step may be missed out whilst going up, but movement is always upwards' (Crawford 2009: 825).

It is well-established that constructing a body of rules does not drive out discretion (Hawkins 2002). So, whilst there is obviously a degree of formalism inherent in the identification and ranking of interventions within a tiered approach like Swansea's, it does not follow that this leaves no scope for discretionary decisionmaking and judgment. Indeed, interviewees' accounts of stages two and three do not depict a mechanistic process, but a relatively flexible one which is guided by the exercise of professional skill and judgment. Importantly, and in contrast to New Labour's interpretation of the regulatory pyramid, interviewees stressed the importance of a shared commitment to avoiding escalation and keeping young people 
from entering the formal youth justice system. As one interviewee explained, 'In some areas a young person can move very swiftly through the whole system ... In Swansea there's less of a desire to process young people upwards through the stages without trying to tackle the problems or the underlying problems that are contributing to the behaviour' (I10). So, for example, if following a stage two warning letter and visit a young person is once again found to have been responsible for anti-social behaviour, the decision may not be to escalate to stage three but to send another letter and/or make another personal visit:

'These stages are so flexible ... If it's at stage 2 and it's a very simple breach I'll send them another letter to say "We're quite disappointed that although you signed the personal warning you have breached it" ... Or, for a slightly more serious [breach], I will say [to the ASB Case Manager] "Why don't you go out and visit them and reiterate face to face that they've signed the Personal Warning?" If they continue to breach then we will call the case conference. Again it's all on a case by case basis' (I7)

Similarly, if a young person is responsible for further anti-social behaviour following an intervention agreed at a stage three case conference, a further case conference will be called. Whilst one option would be to apply for an ASBO, interviewees all agreed that this would be a 'last resort' (I1; I7). One interviewee remarked, 'I want to make sure that young person has every opportunity not to get the ASBO' (I2). The case conference would therefore consider other possible informal interventions, such as FGC and/or an ABC. In some instances, the stage three case conference might even opt for another stage two warning letter and personal visit.

A further significant development in this regard is the creation of the Swansea Bureau. The decision-making powers vested in the police by the 1998 Crime and Disorder Act's introduction of the system of reprimands and final warnings amounted to single-agency 'colonisation' of the front end of the youth justice system (Goldson 2000). The Bureau, which has received the endorsement of the Independent Commission on Youth Crime and Antisocial Behaviour (2010), undoes this by injecting a multi-agency decision-making forum into the process (for a detailed account see Haines and Charles 2010). When a young person is arrested and appears before a police custody officer, the officer will bail the case (for a period of 14-21 days) and refer the matter to the Bureau if three criteria are met: (1) the young person has no previous convictions; (2) the young person admits his involvement in the offence; and (3) the offence has a gravity rating of 3 or less (e.g., theft, public disorder). There then follows a dual assessment process: one for the young person; another for any identified victim. The Bureau Panel (consisting of the Bureau Coordinator, a Police Sergeant and a community representative) considers these assessments and any recommendations and reaches an interim decision. Following the Panel, the Bureau Clinic (consisting of the Bureau Co-ordinator, a Police Sergeant, the young person and, should they wish, their parents/carers) will be held later the same day. The Clinic is participatory in nature, with both the young person and their parents/carers given the opportunity to contribute, including challenging Bureau recommendations. Following discussion the Clinic reaches a final decision on whether the young person should be prosecuted, issued with a reprimand or final warning, or given a non-criminal disposal. Tailor-made services may also be offered (to both the young person and the victim). In keeping with a child-rights approach, these services are intentionally not presented as sanctions or punishments. They are 
designed to be reintegrative, regenerative and restorative, promoting pro-social engagement and behaviour (Haines and Charles 2010). Interviewees stressed that the philosophy underpinning the Swansea Bureau is to divert young people away from entering the youth justice system. As one commented, 'The intention is to use it to ensure that young people do not unnecessarily get hoovered up into the criminal justice system' (I1).

\section{Consistency and avoiding net-widening}

A further claimed benefit of the Bureau is that it helps ensure consistency of interpretation. Several interviewees noted how the much-criticized statutory definition of anti-social behaviour (Ashworth et al. 1995; Ashworth et al. 1998; Macdonald 2006) often overlaps with low-level criminal offences such as criminal damage, public disorder and the misuse of off-road vehicles. ${ }^{3}$ They stated that this results in a disparity of treatment of young people, as similar incidents are sometimes construed as anti-social behaviour and sometimes dealt with as crime. One interviewee explained, 'The problem we've experienced in the past is that [some forms of behaviour] come down both routes ... Some [instances] are anti-social behaviour, some are a criminal matter' (I4), while another remarked, 'With one person it's a criminal offence and another it's anti-social behaviour' (I10). Given the different consequences involved, interviewees considered this to be unfair:

'I've seen similar incidents with young people with similar backgrounds which have been dealt with one with anti-social behaviour where they attract no future record at all and one in the criminal justice system where they're on the police national computer, where they've been swabbed, their DNA has been taken and those things are retained forever. You can't have those two operating ... You shouldn't have a starting point where a similar profile leads to completely different outcomes' (I1)

In Swansea's tiered approach, the ASB Unit has an important role to play in ensuring that young people are not dealt with disparately in cases which could be construed as either anti-social behaviour or crime. After receiving a referral in such a case, the ASB Unit will decide whether to proceed with an anti-social behaviour intervention or whether the case should be filtered out and dealt with under the criminal law. The problem, though, is that cases only reach the ASB Unit if a referral is made, and so it would be possible for a police officer to deal with an incident as a criminal offence without referring it to the ASB Unit even though such an incident would normally be construed as anti-social behaviour. Interviewees explained that the introduction of the Bureau addresses this problem, since when it considers a case one of the options available to it is to refer the case to the ASB Unit to be dealt with as anti-social behaviour. In fact, it was suggested that, in a case which could be construed as either anti-social behaviour or crime, there are advantages in dealing with it as anti-social behaviour. Anti-social behaviour interventions were perceived as inherently more

\footnotetext{
${ }^{3}$ The statutory definition of anti-social behaviour is found in section 1(1)(a) of the Crime and Disorder Act 1998. The basic criminal damage offence is contained in section 1(1) of the Criminal Damage Act 1971, the public order offence of causing harassment, alarm or distress is contained in section 5 of the Public Order Act 1986, and the power to seize vehicles that are being used in a manner that causes alarm, distress or annoyance is contained in section 59 of the Police Reform Act 2002.
} 
flexible and allowing greater opportunity for providing support than the issuance of a reprimand under the youth justice system of reprimands and warnings:

'It enables us to (as long as it's appropriate) have much more flexibility in what we do ... [The] reprimand was no YOS intervention at all, simply the police telling a young person or parent "Don't do it again next time and off we go" so no victim engagement whatsoever, no real way of dealing with the youngster or parent around the issue. The failure rate on reprimands in terms of speed of re-offending by a young person has been notorious really' (I1)

Consistency of approach is important in furthering another objective which was identified by several interviewees - to avoid net-widening. One of the hallmarks of New Labour's youth justice was the use of civil orders and powers that could be made other than as a sentence for a criminal offence. Whilst it may be possible to construe this as defining deviancy up, it has had the paradoxical result of progressively lowering public tolerance to incivility (Muncie and Goldson 2006). Actuarialism has rendered discriminatory fears of young people acceptable and apparently rational, by cloaking them in respectability using ostensibly scientific means of identifying and measuring risk (Smith 2006). Several of the Swansea interviewees opined that today there are greater levels of intolerance of young people than in previous generations. This is exacerbated by the focus of the statutory definition of anti-social behaviour on the effect of the behaviour on others, which means that it depends largely on people's behavioural expectations and norms of aesthetic acceptability (Millie 2008). Interviewees accordingly urged the importance of distinguishing between behaviour which is anti-social and behaviour which is merely adolescent. One stated that 'We have to arbitrate whether the behaviour is anti-social or whether it is more adolescent behaviour which is not accepted by adults but may not constitute being anti-social' (I1), whilst another warned that we must be 'very careful of not criminalising behaviour which really is a rite of passage for the want of a better way of putting it' (I7). They also described local initiatives which are designed to be inclusive and encourage the engagement and participation of young people. For example, one interviewee described a project involving intergenerational work between young perpetrators of anti-social behaviour and over-50s which seeks to nurture each generation's understanding of the other:

'[I]f you get most old people talking about what they think is wrong and you get them to consider what it was like when they were young you start to get a very different response ... [P] art of what we're doing with the intergenerational work is we're trying to make those connections. As people get older they forget about adolescence and the torture of it and what we're trying to do is reconnect them with their own experiences' (I1)

\section{Inclusionary welfarism and multi-agency partnership}

In 2000 the Home Office's Policy Action Team 8 noted a lack of evidence regarding the causes of anti-social behaviour but identified a number of risk factors, with lone parents, homelessness, mental health problems and drug dependency among the most common (Policy Action Team 8 2000). A Home Office Research Study of ASBOs found that underlying factors including alcohol and drug abuse, problems at school, learning disabilities, psychological problems and poor parental supervision 
appeared to have contributed to the individual's anti-social behaviour in a high proportion of cases (Campbell 2002). This was echoed by the report of the Home Affairs Committee in 2005, which stated that young perpetrators of anti-social behaviour often suffer from serious disadvantages and social exclusion, and have significant support needs (Home Affairs Committee 2005). A study of 66 offenders of all ages commissioned by the Home Office's Anti-Social Behaviour Unit found that: approximately 20 percent lived in hostels or other temporary accommodation or were sleeping rough; a large number were unemployed or on sickness benefits; many had not obtained any educational qualifications or training; and, over two-thirds reported problems with alcohol or illegal drug dependency. Moreover, many of the young people in the study reported living with parents or families that were violent, had psychological or drug problems, or were offenders themselves (Matthews et al. 2007; see also Wain 2007). The Youth Justice Board's study of over 100 young people subject to an (interim, standalone or post-conviction) ASBO found that almost half were living in lone-parent households, one-third lived in deprived households, 30 percent were living with known offenders, two-fifths had experienced inconsistent supervision/boundary setting, and approximately one in six had experienced some form of abuse before receiving an ASBO (Solanki et al. 2006; see also Koffman 2006). Meanwhile, projects set up to intervene with families responsible for antisocial behaviour have found that often these are 'very disadvantaged families' who face a 'high level of risk, including poor parenting, health problems, substance misuse, family breakdown and domestic violence' (White et al. 2008: 4). Within these families the number of young people not in education, training or employment was well-above the national average at 35 percent. Coupled with the experience of practitioners, studies like these have contributed to a shift away from an emphasis on the use of enforcement powers towards greater use of supportive and preventive interventions (Crawford et al. 2009).

There are, however, both methodological and ethical reasons to be wary of the risk factor prevention paradigm (Case and Haines 2009; Kemshall et al. 2006). As the language of need, at risk and vulnerability elides into the language of risk, harm and danger (Kemshall 2008), actuarialism results in a preoccupation with risk at the expense of need (Smith 2006). There is a blurring of social policy and crime policy, with social problems reframed as crime problems and crime control strategies used to manage social ills (Kemshall 2008). Inclusionary welfarism is displaced by exclusionary punitivism, and notions of family support and relief are reframed as questions of parental (ir)responsibility and family failure (Goldson and Muncie 2006). Social and collective risks are thus transformed into individual ones (Kemshall 2008), with structural explanations and material contexts marginalized (Muncie and Goldson 2006). This process of responsibilization results in the problematizing of youth. The constructionist gaze shifts from the child as victim to the child as threat, and the child in need construct is substituted by a responsibilized and adulterized young offender (Goldson and Muncie 2006).

The manner in which New Labour deployed regulatory ideas and concepts in the context of youth anti-social behaviour is a prime example of both exclusionary punitivism and the responsibilization and adulterization of young people. These ideas and concepts are geared towards the regulation of business actors and so cannot simply be straightforwardly applied to perpetrators of anti-social behaviour, who may have quite different motivations, capacities and competencies (Crawford 2009). For example, in their work on responsive regulation Ayres and Braithwaite assert that 'most business actors are bundles of contradictory commitments to values of 
economic rationality, law abidingness, and business responsibility' (Ayres and Braithwaite 1992: 31). Different selves prevail at different moments and in different contexts. It would therefore be premature, they argue, to assume that certain offenders are incorrigible and that a strategy based on forgiveness will only be exploited: '[E]ven within business executives who most of us would typify as ruthless, there is a glimmer of a socially responsible self that can be drawn to the fore in a regulatory encounter' (Ayres and Braithwaite 1992: 33). In stark contrast, young people are engaged in a process of maturation and so are still developing a socially responsible self. Indeed, the Swansea interviewees stressed that many young people lack empathic skills, adding that they will often desist from further misconduct once they appreciate the effect of their behaviour on other people. So, for example, one interviewee described the tiered approach in Swansea as 'part of the learning process for that young person ... It's about looking at the consequences of their behaviour for other people in the community and understanding it' (I4). Another discussed the intergenerational work referred to previously, saying that it was only once the project was complete that the young people came to understand that what they'd been doing was 'not the right thing to do' (I1). A third described work done by the Youth Offending Service in local schools, in which pupils are given scenarios to discuss which involve anti-social behaviour and asked how they would feel if the same thing happened to them or to a member of their family - to which a common response is '[I] didn't think of that' (I2). To simply assume that young perpetrators of anti-social behaviour have a socially responsible self would be to adulterize them and neglect the need to educate them about social responsibility.

Moreover, the structural position of young perpetrators of anti-social behaviour is quite different to that of business actors. While light touch regulation and discretion are taken as the norm in the business world, and so the possibility of tough sanctions is vital to underline regulators' power, many young perpetrators of anti-social behaviour face difficult personal circumstances and have (often multiple) support needs. Yet the New Labour Government encouraged using the threat of sanctions to induce them to comply with preventive interventions (see further below). When this happens, 'It is no longer about rights to universal welfare services, but about increasingly corrective and compulsory services, and diminished rights to refuse the regulation of the State' (Kemshall 2008: 28). This exclusionary punitivism may be contrasted, however, with the social policy orientation of the Welsh Assembly Government's response to crime and disorder (Edwards and Hughes 2008), which stems from a social democratic impulse to engineer social integration through more intensive welfare state interventions (Edwards and Hughes 2009). The Welsh Assembly Government has established ten universal entitlements for all children in Wales (Welsh Assembly Government 2002). In contrast to the approach in England, the Welsh approach eschews notions of risk, responsibility or containment and recognizes that all children (including those who offend) have these basic entitlements as of right and it is the responsibility of those adults who work with children to ensure that all services are provided in a manner which maximizes the extent to which children access their entitlements (Haines 2009).

Consistent with this approach, a recurring theme amongst the Swansea interviewees was the importance of multi-agency working to tackling anti-social behaviour and its causes. As well as facilitating access to a range of specialist services (as one interviewee said, '[When] dealing with anti-social behaviour you can't deal with it on your own because there's so many issues. I couldn't deal with those specialist issues. You need those other agencies for support' (I3)), a partnership 
approach nurtures a sense of collective responsibility which stops agencies from attempting to evade responsibility for addressing an individual's support needs ('Before it was easy to ... send it to social services so they have the decision. Where we're going is that it's not the decision of the social services, it's not the decision of the police, it's the decision of us all because we've all got to work together on this and if it goes wrong its going to be on us all' (I5)). Moreover, interviewees opined that the pooling of expertise and the (admittedly sometimes difficult) process of discussion and negotiation involved in partnership working results in more informed decisionmaking. However, the different priorities and perspectives of the agencies involved require that there is a shared commitment to partnership working and to meeting the support needs of young people ('We're dependant on the overriding ethos being maintained and when a threat comes along that a key agency doesn't run to the bunker' (I10)). Interviewees also identified other significant challenges to multiagency efforts to address individuals' support needs. In particular, there are some agencies, such as Education, which are not represented within the partnership in Swansea even though they could have an important role to play in tackling some of the problems which commonly underlie anti-social behaviour. There are also issues regarding agencies' willingness to share information, as well as the need to ensure that suitable structures and procedures are in place for information to be conveyed effectively. And interviewees expressed concern that partnership working may be one of the first casualties of budgetary constraints and cuts.

\section{Voluntarism, engagement and compliance}

Punitivism pervaded New Labour's guidance on the use of anti-social behaviour interventions. Such guidance repeatedly told practitioners that informal interventions should be accompanied by a clear warning about the action that may be taken in the event of non-compliance. For example, guidance stated that (written or verbal) warnings should inform individuals that their behaviour is anti-social and unacceptable, advise them that their behaviour is being monitored, and 'warn them that there will be further enforcement action if the behaviour does not cease' (Home Office 2008: 10). It stated that an ABC should include an outline of the consequences of non-compliance, adding that 'The threat of legal action provides an incentive to ensure adherence to the ABC' (Home Office 2008: 10). And, in a similar vein, guidance on the Respect website on how to respond effectively to challenging families stated 'Sanctions are key', adding that 'The threat of sanctions or use of sanctions implemented to provide [sic.] both a way of curbing bad behaviour but also providing a lever for persuading people to accept and cooperate fully with the offers of help' (Home Office 2010). This ominous tone is difficult to reconcile with the notion that voluntary participation is as an important feature of contractual instruments likes ABCs and Parenting Contracts. The rationale of contractual governance is said to be that if the parties participate in the contractual deliberations and voluntarily co-opt into the values and norms underlying the agreement they are more likely to believe they have ownership of it and comply with its terms (Crawford 2003). However, the 'impression of voluntarism control contracts gain by association with the ideology of the market ... [was] contradicted by the fact that one cannot really refuse to enter into a state-based control contract, as contracting is usually linked to avoidance of an immediate penal sanction or the receipt of a necessary "good" such as housing' (Mackenzie 2008: 228). 
Ironically (given New Labour's deployment of regulatory ideas and concepts), foreboding threats of possible sanctions are also at odds with one of the principles at the heart of responsive regulation - the minimal sufficiency principle. This principle maintains that "the less salient and powerful the control technique used to secure compliance, the more likely that internalization will result ... [L]ong-term internalization of values like altruism and resistance to temptation is inhibited when [actors] view their action as caused by a reward or punishment' (Ayres and Braithwaite 1992: 49). Ayres and Braithwaite accordingly stated that punishment should be kept in the background for actors who are intrinsically motivated to comply, and only made salient for actors who can only be moved by bringing forward the extrinsic incentive. The same logic is found in Braithwaite's work on restorative justice. While an inexorable commitment to the use of escalating interventions of increasing intrusiveness in the event of non-co-operation is necessary, reasoning should be used in preference to power assertion. He explains that threats are counterproductive because they increase a process called reactance. When threats are made which thrust punishment into the foreground, 'other-regarding deliberation is made difficult because the offender is invited to deliberate in a self-regarding way out of concern to protect the self from punishment. This is not the way to engender empathy with the victim, internalization of the values of the law and the values of restorative justice' (Braithwaite 2002: 36). The issuance of authoritarian guidance by the Home Office failed to heed this message.

The Swansea interviewees explained that young people who have behaved anti-socially are told about the four-staged tiered approach, with the consequences of continued anti-social behaviour clearly explained to them. Significantly, however, all interviewees strongly emphasized that this information is not presented as a threat. Instead, they said that such values as honesty and fairness require that young people are informed of the potential consequences of non-compliance. For example, one interviewee stated:

'I think it's really important to be upfront and honest with young people. This should be an exchange of information. It shouldn't be perceived as an out and out threat, the purpose being to frighten them into changing their behaviour, but rather saying "Let's look at this and put all the options on the table, lets give you your choices and explain to you the outcome of the decisions that you make". So it isn't just wagging the finger, it isn't threatening, it isn't purely a coercive measure. It's rather being frank, giving information in a frank and straightforward way that perhaps they hadn't come across' (I8)

In spite of this, interviewees' accounts of the operation of $\mathrm{ABCs}$ at stage three of the tiered approach reveal tension with the principles of voluntarism and participation. Even though all interviewees emphatically insisted that $\mathrm{ABCs}$ are a voluntary undertaking and that the possibility of escalation is never used as a threat, most opined that those young people who do co-operate probably do not perceive their engagement as voluntary. For example, one interviewee remarked, 'I think they feel that they have to [sign up]' (I3), whilst another likened the decision whether to enter into an $\mathrm{ABC}$ to the decision whether to pay taxes, concluding 'I dare say the argument for participating is so strong it's almost involuntary' (I8). In fact, some interviewees said that they downplay the voluntary nature of $\mathrm{ABCs}$ in order to ensure that young people enter into them. One said 'I don't think we bang on about it being 
voluntary to them because if they think "I don't have to do this" they won't want to do it' (I3), whilst another said:

'We try not to give them that impression [that $\mathrm{ABCs}$ are voluntary]. It will be explained but it's mentioned at the end because we're trying to work with that young person, so we say "You need to do this" and a lot of them when they get to this stage they do knuckle down and work with us' (I2)

Awareness of the potential consequences of non-compliance was also identified as being one of the reasons why young people desist from further antisocial behaviour. For example, interviewees commented that 'There comes a point where they start realising there's going to be consequences' (I4), 'Where they abide by [an $\mathrm{ABC}$ ] I think that the primary motivation is the understanding, perhaps for the first time, of the consequences' (I8), 'I think it's the realization of what they're doing and what can happen and the effect their behaviour is having' (I3), and 'By ABC stage a young person realizes we really are quite serious about sorting this behaviour out' (I7). Importantly, though, such awareness was not identified as being the sole, or even necessarily the predominant, reason for compliance. The relationship the young person forms with the ASB Case Manager or ABC Project Worker was regarded as very important, as it provides the young person with a source of support and a person they can talk to and trust. Also important are the support services made available to the young person, and the provision of diversionary activities which seek to replace the anti-social behaviour with some other interest or pastime. And the process is designed to be educative, making young people aware of the impact of their behaviour on others. One interviewee explained:

'In terms of child development, one of the last things that develops and is slower with boys than girls is the ability to think yourself into a situation. So when we talk about victim empathy, it's not really something that develops within the consciousness of teenagers until they're in their late teenage years. So sometimes we're going to be looking at people who are 14-15 years of age who, when they say they're not aware of their actions, they're not just saying that - they really are not. What we're seeking to do is create a situation in which we educate them. We're not talking necessarily about an enforcement regime which prevents them doing things by curfew, etc' (I1)

The findings from Swansea thus support Field's conclusion that, for many social workers, the concern for the welfare of young offenders has been 'reconstituted in terms of a more qualified voluntarism in relationships with young people' (Field 2007: 326).

\section{Conclusion}

\section{Muncie p52}

The New Labour Government's approach to youth anti-social behaviour was characteristic of its broader approach to youth justice. Its portrayal of the tiered approach reflects its movement towards early interventionism and advocates a commitment to escalating forms of intervention. At the same time, actuarialism has not only fostered lower thresholds of intervention and progressively lower levels of public tolerance to incivility, but cloaked this in respectability. It has also resulted in 
a preoccupation with risk at the expense of need. Social problems have been recast as crime problems, and social risks transformed into individual ones. This movement from inclusionary welfarism to exclusionary punitivism is exemplified by the use of authoritarian threats of sanctions to induce young perpetrators of anti-social behaviour to comply with preventive interventions.

Alongside these 'grand narrative themes' which characterized New Labour's New Youth Justice (Edwards and Hughes 2008: 63), it must also be recognized that it is not possible to speak of a 'unitary British model' or 'ASBO Nation' (Edwards and Hughes 2008: 69). At a time at when there is concern that the Scots youth justice is losing its distinctive character and being undermined by policies imported from south of the border (McAra 2006), it is significant that a distinctive policy agenda is emerging in devolving Wales. With its roots in social democratism, the Welsh response to crime and disorder is oriented towards more intensive and inclusive welfare state interventions. Its children-first approach stresses that all children, including those who offend, have basic entitlements as of right and emphasizes the responsibility of those working with children to ensure that children receive the services to which they are entitled. Devolution has provided space for the Welsh Assembly Government to formulate its own distinctive policy agenda. It must be recognised that even within a relatively small jurisdiction such as Wales there is scope for practices to diverge from the policy objectives established by national (devolved) government (Muncie, 2011). It is also important to recognize that youth justice systems are 'dynamic and ever-changing sites of contestation and change' (Goldson and Muncie 2006: 204) in which policies may be mediated by practitioners (Kemshall 2008) and those who seek to govern are power-dependent on others to carry out their commands (Edwards and Hughes 2009). This is powerfully illustrated by the Swansea interviewees' accounts of the city's tiered approach to youth anti-social behaviour. In stark contrast to New Labour's early interventionism, and consistent with the Welsh Assembly Government's approach to children's policy, these accounts repeatedly emphasised the importance of diverting young people from the formal youth justice system and avoiding net-widening. Interviewees from all agencies also stressed the importance of multi-agency partnership and the collaborative provision of support services and preventive projects which are inclusive and engage young people. So despite the dominant trends elsewhere in the UK, this set of local policymakers and practitioners strongly promoted an approach in which young people are regarded as 'children first and offenders second' (Welsh Assembly Government 2004: 3).

\section{Acknowledgements}

To follow

\section{References}

Ashworth, A., Gardner, J., Morgan, R., Smith, A.T.H., von Hirsch, A., and Wasik, M. (1995), 'Overtaking on the Right', New Law Journal, 145: 1501-1502 \& 1516.

Ashworth, A., Gardner, J., Morgan, R., Smith, A.T.H., von Hirsch, A., and Wasik, M. (1998), 'Neighbouring on the Oppressive: The Government's "Anti-Social Behaviour Order" Proposals', Criminal Justice, 16/1: 7-14. 
Ayres, I., and Braithwaite, J. (1992), Responsive Regulation: Transcending the Deregulation Debate. New York: OUP.

Braithwaite, J. (2002), Restorative Justice and Responsive Regulation. New York: OUP.

Campbell, S. (2002), A Review of Anti-Social Behaviour Orders, Home Office Research Study 236. London: Home Office.

Case, S. (2004), Promoting Prevention: A Multi-Agency Initiative to Prevent Youth Offending Through Consultation in Swansea Schools. Doctoral Thesis. Swansea: Swansea University.

Case, S., and Haines, K. (2009), Understanding Youth Offending: Risk Factor Research, Policy and Practice. Cullompton: Willan Publishing.

Crawford, A. (2003), “'Contractual Governance” of Deviant Behaviour', Journal of Law and Society, 30/4: 479-505.

Crawford, A. (2009), 'Governing Through Anti-Social Behaviour: Regulatory Challenges to Criminal Justice', British Journal of Criminology, 49/6: 810-831.

Crawford, A. et al. (2009), Situating Anti-Social Behaviour and Respect, ESRC Findings. Leeds: CCJS Press, available online at www.law.leeds.ac.uk/esrcASB (last visited 14 April 2010).

Drakeford, M. (2010), 'Devolution and Youth Justice in Wales', Criminology and Criminal Justice 10/2: 137-54.

Edwards, A., and Hughes, G., (2008), 'Resilient Fabians? Anti-social Behaviour and Community Safety Work in Wales', in P. Squires, ed., ASBO Nation: The Criminalisation of Nuisance, 57-72. Bristol: The Policy Press.

Edwards, A., and Hughes, G. (2009), 'The Preventive Turn and Promotion of Safer Communities in England and Wales: Political Inventiveness and Governmental Instabilities', in A. Crawford, ed., Crime Prevention in Europe: Comparative Perspectives, 62-85. Cullompton: Willan Publishing.

Fergusson, R. (2007), 'Making Sense of the Melting Pot: Multiple Discourses in Youth Justice Policy', Youth Justice 7/3: 179-94.

Field, S. (2007), 'Practice Cultures and the "New" Youth Justice in (England and) Wales', British Journal of Criminology 47/2: 311-30.

Goldson, B. (2000), 'Wither Diversion? Interventionism and the New Youth Justice', in B. Goldson, ed., The New Youth Justice, 35-57. Lyme Regis: Russell House Publishing. 
Goldson, B., and Hughes, G. (2010), 'Sociological Criminology and Youth Justice: Comparative Policy Analysis and Academic Intervention', Criminology and Criminal Justice 10/2: 211-30.

Goldson, B., and Muncie, J. (2006), 'Critical Anatomy: Towards a Principled Youth Justice', in B. Goldson, and J. Muncie, eds., Youth Crime and Justice: Critical Issues, 203-31. London: Sage.

Haines, K. (2009), 'The Dragonisation of Youth Justice', in W. Taylor, R. Earle, and R. Hester, eds., Youth Justice Handbook: Theory, Policy and Practice, 231-42.

Cullompton: Willan Publishing.

Haines, K., and Case, S. (2003), 'Promoting Positive Behaviour in Schools: The Youth Social Audit', Youth Justice 3/2: 86-103.

Haines, K., and Charles, A. (2008), HYPE: Helping Young People by Peer Education: A Process Evaluation. Swansea: Swansea University

Haines, K., and Charles, A. (2010), The Swansea Bureau: Children First, Offending Second. Report submitted to Swansea Youth Offending Service.

Hawkins, K. (1992), 'The Use of Legal Discretion: Perspectives from Law and Social Science' in K. Hawkins, ed., The Uses of Discretion, 11-46. Oxford: Clarendon Press.

Home Affairs Committee (2005), Anti-Social Behaviour, Fifth Report of Session 2004-05 HC 80. London: The Stationery Office.

Home Office (2006), Anti-Social Behaviour Tools and Powers. London: Home Office.

Home Office (2008), A Guide to Anti-Social Behaviour Tools and Powers. London: Home Office.

Home Office (2010), 'Achieving LAA Outcomes', available online at http://www.asb.homeoffice.gov.uk/members/article.aspx?id=12032 (last visited 14 April 2010) (copy on file with authors).

Home Office (2011), More Effective Responses to Anti-Social Behaviour. London: Home Office.

Hughes, G., and Follett, M. (2006), 'Community Safety, Youth and the "AntiSocial"', in B. Goldson, and J. Muncie, eds., Youth Crime and Justice: Critical Issues, 157-71. London: Sage.

Independent Commission on Youth Crime and Antisocial Behaviour (2010), Time for a Fresh Start: The Report of the Independent Commission on Youth Crime and Antisocial Behaviour. Available at:

http://www.youthcrimecommission.org.uk/attachments/076_FreshStart.pdf (last checked 10 August 2010). 
Kemshall, H. (2008), 'Risks, Rights and Justice: Understanding and Responding to Youth Risk', Youth Justice, 8/1: 21-37.

Kemshall, H., Marsland, L., Boeck, T., and Dunkerton, L. (2006), 'Young People, Pathways and Crime: Beyond Risk Factors', Australian and New Zealand Journal of Criminology, 39/3: 354-70.

Koffman, L. (2006), 'The Use of Anti-Social Behaviour Orders: An Empirical Study of a New Deal for Communities Area', Criminal Law Review: 593-613.

Lemert, E. (1967), Human Deviance, Social Problems and Social Control. Englewood Cliffs, NJ: Prentice Hall.

Macdonald, S. (2006), 'A Suicidal Woman, Roaming Pigs and a Noisy Trampolinist: Refining the ASBO's Definition of Anti-Social Behaviour' Modern Law Review, 69/2: 183-213.

Mackenzie, S. (2008), 'Second-chance Punitivism and the Contractual Governance of Crime and Incivility: New Labour, Old Hobbes', Journal of Law and Society, 35/2: 214-239.

Matthews, R., Easton, H., Briggs, D., and Pease, K. (2007), Assessing the Use and Impact of Anti-Social Behaviour Orders. Bristol: The Policy Press.

May, T. (2010) 'Moving Beyond the ASBO', speech delivered at the Coin Street Community Centre, London, 28 July 2010.

McAra, L. (2006) 'Welfare in Crisis? Key Developments in Scottish Youth Justice' in J. Muncie, and B. Goldson, eds., Comparative Youth Justice: Critical Issues, 127-45. London: Sage.

McAra, L., and McVie, S. (2010), 'Youth Crime and Justice: Key Messages from the Edinburgh Study of Youth Transitions and Crime', Criminology and Criminal Justice, 10/2: 179-209.

Millie, A. (2008), 'Anti-social Behaviour, Behavioural Expectations and an Urban Aesthetic', British Journal of Criminology 48/3: 379-394.

Ministry of Justice (2010), Breaking the Cycle: Effective Punishment, Rehabilitation and Sentencing of Offenders, Cm 7972. London: The Stationery Office.

Moffitt, T. (1993), 'Adolescence-Limited and Life-Course-Persistent Antisocial Behaviour: A Developmental Taxonomy’, Psychological Review, 100/4: 674-701.

Morgan, R. (2009) Report to the Welsh Assembly Government on the question of Devolution of Youth Justice Responsibilities. Cardiff: Welsh Assembly Government.

Muncie, J. (1999), 'Institutionalized Intolerance: Youth Justice and the 1998 Crime and Disorder Act', Critical Social Policy, 19/2: 147-75. 
Muncie, J. (2011), 'Illusions of Difference: Comparative Youth Justice in the Devolved United Kingdom', British Journal of Criminology, 51/1: 40-57.

Muncie, J., and Goldson, B. (2006), 'England and Wales: the New Correctionalism', in J. Muncie, and B. Goldson, eds., Comparative Youth Justice: Critical Issues, 3447. London: Sage.

National Audit Office (2006) Tackling Anti-Social Behaviour, HC 99. London: The Stationery Office.

Policy Action Team 8 (2000), National Strategy for Neighbourhood Renewal: Report of the Policy Action Team 8. London: Home Office.

Puffett, N. (2011), 'Intervene in the early years to bring down youth offending, urges Justice Minister', Children \& Young People Now, 8 February 2011.

Rutherford, A. (1992), Growing out of Crime: The New Era. Winchester: Waterside.

Smith, R. (2006), 'Actuarialism and Early Intervention in Contemporary Youth Justice', in B. Goldson, and J. Muncie, eds., Youth Crime and Justice: Critical Issues, 92-109. London: Sage.

Solanki, A.R., Bateman, T., Boswell, G., and Hill, E. (2006), Anti-Social Behaviour Orders. London: Youth Justice Board.

Swansea Youth Action Network (2010), SYAN Handbook. Swansea: Swansea Youth Action Network.

Wain, N., with Burney, E. (2007), The ASBO: Wrong Turning - Dead End. London: Howard League for Penal Reform.

Welsh Assembly Government (2002), Extending Entitlement: Support for 11 to 25 Year Olds in Wales. Cardiff: Welsh Assembly Government.

Welsh Assembly Government (2004), All Wales Youth Offending Strategy. Cardiff: Welsh Assembly Government/Youth Justice Board.

White, C., Warrener, M., Reeves, A., and La Valle, I. (2008), Family Intervention Projects: An Evaluation of their Design, Set-up and Early Outcomes, Research Report DCSF-RW047. London: Department for Children, Schools and Families. 
Table 1:

\begin{tabular}{|c|c|c|c|c|c|c|c|}
\hline & & 2004 & 2005 & 2006 & 2007 & 2008 & 2009 \\
\hline $\begin{array}{l}\text { Stage } 1 \\
\text { letter }\end{array}$ & $\begin{array}{l}\text { All } \\
\text { ages* }\end{array}$ & 1180 & 1281 & 1377 & 720 & 624 & 1016 \\
\hline \multirow[b]{2}{*}{$\begin{array}{l}\text { Stage } 2 \\
\text { letter }\end{array}$} & All ages & 215 & 282 & 158 & 91 & 119 & 90 \\
\hline & $\begin{array}{l}\text { Young } \\
\text { people }\end{array}$ & $\begin{array}{l}\text { Data not } \\
\text { available }\end{array}$ & 148 & 94 & 69 & 73 & 73 \\
\hline \multicolumn{2}{|c|}{$\begin{array}{l}\text { Acceptable } \\
\text { Behaviour } \\
\text { Contracts with a } \\
\text { young person }\end{array}$} & 9 & 18 & 10 & 3 & 0 & 9 \\
\hline \multicolumn{2}{|c|}{$\begin{array}{l}\text { Anti-Social } \\
\text { Behaviour Orders } \\
\text { on application } \\
\text { against a young } \\
\text { person** }\end{array}$} & 0 & 3 & 0 & 0 & 0 & 0 \\
\hline
\end{tabular}

* The ASB Unit only records the total number of stage 1 letters sent to all ages.

** Since post-conviction ASBOs operate outside the tiered approach, only ASBOs on application have been included in this table.

Source: Swansea ASB Unit 